\title{
'Brisbane will Never be the Same': Tasting Change at World Expo '88
}

\author{
Donna Lee Brien
}

Brisbane will never be the same after Expo - shopping hours, outdoor eating, the greening of the city, our attitudes to hospitality ... all these things will permanently transform our city. (Edwards, quoted in Robson 1988: 54)

\section{Food at World's Fairs}

While food historians have begun to focus attention on world's fairs, Vaccaro's detailed study of food at the 1904 World Fair in St Louis (2004) is at the vanguard of publishing in this area. Similarly, although the intense interest in culinary matters that is now identified as 'foodie' culture was developing in Australia in the 1980s, little attention has concentrated on this aspect of Brisbane's World Expo '88 (also widely known simply as 'Expo '88'), which was staged from April to October 1988 as part of the national Bicentennial celebrations. Expo '88 dominated local headlines and became a part of the national imagination during the bicentennial year but, although commentators at the time predicted that it would 'doubtless be a focus of research for a long time to come' (Day 1988: iv), other matters have since dominated reflection about this period of recent Australian history. ${ }^{1}$ Yet food was specified in the 'Cultural and Entertainment' category of one of the three exposition's official sub-themes of 'Leisure: The Universal Pastime', and did play a number of important roles in and at Expo '88. Moreover, Robinson has identified Expo ' 88 as one of the 'plethora of social, economic, cultural and political determinants' that explains the diversity of cuisines available in Brisbane today (2007: 71).

Food and beverages have long been recognised as part of the attractive bounty that can be displayed, marketed and sold at international expositions. Thus, at the 1924 British Empire Exhibition in Wembley, London, some 25,000 customers dined 
every week in a café stocked with Australian meat, bread, butter, wines and fruit, and more than 75 tons of Australian apples were sold in the first month (McKay 2004: 84-85). By Expo '67 in Montreal, it appeared that Australia was ready to project a more sophisticated culinary image, with refined seafood dishes served on polished pearl shells in the VIP restaurant in a modernistic Robin Boyd-designed pavilion (NatMus 2007). In Brisbane, although the stated theme of 'Leisure in the Age of Technology' focused on the leisure activities that modernity supposedly promotes (and, therefore, not on the physical work of rural production), the large 'Silo in the City' Queensland Primary Industries pavilion reminded visitors that rural industries, including food production, formed the basis of Queensland's economy.

\section{Food as Income Generator}

Although, in a speech to potential international delegates, Prime Minister Hawke explained that the exposition was 'not a trade fair' and exhibitors do 'not sell their goods and services; rather they show and explain ... a part of humankind's endeavours related to a theme' (1986: 771), the outcome of this showcasing at Expo '88 was to be economic. For, again in the prime minister's words, Expo '88 aimed to 'provide a stimulus to business, industry, trade and international investment' (Hawke 1986: 771), and it was estimated that the event would create the equivalent of more than 14,000 full time jobs (some 5,200 directly and the rest in indirect employment) and provide a total economic stimulus of A $\$ 1$ billion to the Australian economy. ${ }^{2}$ The head of the organising Expo Authority, Sir Llew Edwards, stated that the expo was 'purely and simply a commercial proposition' (quoted in Syvret 1988: 52). ${ }^{3}$ Whether a showcase, economic stimulus or commercial venture, a great deal was sold at Expo '88 - and a large proportion of what was purchased was eaten or drunk. The 70 catering outlets on site were able to serve more than 17,000 meals an hour during their 10.00 a.m. to 10.00 p.m. seven-daysa-week opening times (Robson 1988: 53). In addition, visitors could dine later at World Expo Park - the space-themed roller coaster and Fun Park that included The Galaxy and Star Terrace restaurants - and there were also two licensed bistros dedicated to serving the some 30,000 accredited staff, one of which was operational 24 hours a day. Licensed Bicentennial (including Expo '88) products, which included foodstuffs such as wine, ice cream, confectionery and macadamia nuts, generated additional retail sales in excess of A\$100 million in 1987 and 1988 (Marketing World 1987/88: 62). Moreover, Expo '88 needed the income generated by this consumption. Aiming to be the first self-funded world's fair (and at a total estimated cost of some A $\$ 600$ million to stage), planners calculated that 7.8 million paying visitors needed to visit over the 184 days of the exposition, and they needed to spend substantially while they were on the site.

In many previous international expositions, hospitality outlets had been concentrated into a dedicated section, or sections, of the site. At the 1939 New York World's Fair, such an area included a series of restaurants that could each 
seat up to 1,600 diners within pavilions featuring branded meats, dairy products, coffee, cigarettes, beer and whisky (Prohibition ended in 1933), and such processed foods as sliced bread, baby food and soft drinks. The Swedish Pavilion included a restaurant with a revolving, circular table that introduced the word smörgasbord into English, while the Turkish Pavilion hosted a Coffee House and bar where visitors could purchase Turkish specialities (Wurts and Appelbaum 1977). Similarly, many of the ten million visitors to the 1962 Seattle World's Fair ate at the Food Circus, a food hall where 52 different concessions served food from around the world - nine of these also presented exhibits - or more expensively in the revolving restaurant on top of the futuristic Space Needle (Morgan and Wilson 1963). The restaurants, cafés and takeaway food outlets at Expo '88 were, instead, spread across the 42 hectare site, both as part of and separate from the international and corporate pavilions.

Some of the international pavilions' catering venues at Expo '88 were predictable, such as the Britannia Inn, which advertised that it enabled visitors to sample 'some of Britain's finest beers, ciders and traditional food' (British Pavilion 1988). With seating for 300 - 74 inside and 226 outside - diners were entertained by Morris dancers and self-described 'Cockney' musical performers. The large (800-seat) open-air, riverfront and very popular Americana Food Village (AFV), a part of the United States pavilion, promoted itself as presenting 'a cultural smorgasboard' of so-called 'traditional' food and beverages from Hollywood, Honolulu, New York, New Orleans and Anchorage (Walsh and Hall 1988: 78). However, sponsored by well-known brands including Coca-Cola, Baskin-Robbins, Jim Beam and Gatorade, it largely provided the deep-fried fast food expected by purchasers. Fourth of July celebrations in the AFV, for instance, included fried chicken and apple pie, but these 'pies' were fried apple-filled pastry pockets. The Canadian pavilion featured 'traditional Canadian specialities', the Korean pavilion's Seoul Restaurant 'traditional' bulgogi (broiled marinated beef) with kimchi (pickled chilli vegetables), and the Russian pavilion's Troika restaurant 'traditional dishes from Soviet regions', accompanied by balalaika gypsy music (Walsh and Hall 1988: 80; USSR Pavilion 1988). The Hungarian pavilion's fine-dining restaurant, the Budapest — with its much-remarked panorama of the city - together with the restaurants and other food outlets in the Cyprus, Malaysia, Nepal, Pakistan and Singapore pavilions each mentioned such 'traditional foods' or words to that effect in their menus or publicity. As noted by Bennett, such marketing of 'tradition' disrupted the rhetoric of technological modernism that animated many of the hi-tech multimedia, multiscreen presentations of contemporary leisure activities displayed in these pavilions (1992: 129). Further disconnections between pavilion exhibits and their restaurants included the Philippine complex serving what it termed 'typical Filipino snacks and drinks' in its indoor/outdoor refreshment area, but not the roasted suckling piglet pictured in the exhibit (Philippine Pavilion 1988). Even more discordantly, the Queensland Teachers' Credit Union 'outer space'-themed pavilion distributed some one million packages of freeze-dried ice cream: originally developed for NASA, the ice cream was especially imported from the United States (Syvret 1988: 57). Such inauthenticity was not limited to culinary matters: the Canberra 
pavilion hung a copy of Jackson Pollock's controversial Blue Poles (the original of which hung in the National Gallery of Australia) because the pavilion organisers claimed that they could not risk hanging the valuable painting in such a public venue (NCDA 1988).

Other pavilions were more integrated in their information messaging and marketing. One of the most deluxe (and expensive) dining venues at Expo '88 was the Terrace Restaurant in the Swiss pavilion. Owned and operated by the Zurichbased Swissair company ICS Catering Services, the Terrace looked out over the contents of the extremely popular $\mathrm{A} \$ 11$ million pavilion, which featured a chairlift over, and slalom ski ramp down, a mini-mountain of snow kept spectacularly frozen in sub-tropical Brisbane. The image projected was of wealth and, fittingly, the Terrace had its own gold-embossed business cards to advertise its prescient promotion of local specialities and chefs from each of the Swiss cantons. Unlike most of the Expo eateries, the Terrace took reservations for its lengthy waiting list. In keeping with the Swiss banking profiled in the pavilion, each diner was presented with a gold-wrapped chocolate coin at the end of the meal. Moreover, these coins were 'occasionally' replaced with 'the real thing', although there was clearly some doubt regarding whether diners would be able to handle this substitution safely, and each table carried the following warning:

So pick up your coin. Does it feel extra heavy? It does! Well, congratulations! Please though, don't bite a piece out of it. It's worth $\$ 160$ but consider the dentists [sic] bill! (Swiss Pavilion 2008)

New Zealand, its pavilion unique at Expo '88 in being designed by a youth commission that included schoolchildren, featured the same food in its displays and catering venues. The region of Marlborough, for instance, was promoted in the pavilion as a 'gourmet's paradise' with 'an abundance of superb wines and foods' and deer, pig and goat hunting and fishing a feature (Matheson and Randle c.1988). The Lockwood Lodge 'buffeteria', set at lagoon's edge in the South Pacific Village area which also featured a Pacific restaurant specialising in so-called 'South Seas' food, mimicked the series of luxury (hunting) lodges situated around New Zealand, and duly featured those Marlborough meats, fish and wines on its menu. Local dairy foods were similarly highlighted in the pavilion and then marketed in a New Zealand ice cream outlet. On a smaller scale, visitors emerged from the Queensland pavilion into a venue that served fresh fruit salad and sundaes utilising the tropical fruits pictured so appetisingly in the pavilion, many of which were sourced (relatively) locally. The Queensland Primary Industries pavilion similarly included an unlicensed food plaza, but it was one of the few corporate pavilions that dealt directly with food of any kind - Cadbury confectionery and Kona Hawaiian coffee (which had its own coffee lounge as well as being served in many of the site's restaurants) being exceptions. As a sponsor and official supplier of confectionery to the event, Cadbury spent more than A $\$ 1.5$ million on Expo '88, making this the major activity of its 1988 marketing program. The company featured an operating chocolate-moulding plant, together with a simulated 
cocoa plantation in its pavilion, but also devoted over 10 per cent of the space to sales, including its range of commemorative products (Syvret 1988: 56). Despite such sponsorships, Expo '88 largely avoided the criticism of Vancouver's Expo '86 which, with McDonald's as its official caterer, was widely called 'McExpo' (Craik 1989: 100).

In retrospect, some of the food sold at Expo '88 was not only authentic, but also in advance of public taste. The menu from the restaurant in the Sri Lanka pavilion, for instance, included many vegetarian dishes such as hoppers, crispy-edged pancakes made from rice flour that were baked over an open fire and served plain or with curries, spiced lentils and chickpea dishes. Desserts such as coconut and honey pancakes, and the traditional watalappam - a pudding made of Sri Lankan jaggery (sugar), eggs and milk — were offered with Ceylon tea and passionfruit juice. A coda to the menu asserted the authenticity of the food while dismissing concerns about hygiene, promising that all foods served were 'prepared up to the highest Australian standards daily in the restaurant kitchen by highly qualified ... Sri Lankan professional chefs' (Sri Lankan Pavilion 1998). To counter concerns about food standards, the Dubrovnik Restaurant in the Yugoslavian pavilion advertised that it was run by locally based 'international caterers and consultants'. The Dubrovnik offered a menu of unfamiliar soups, exotic meat dishes and authentic desserts. ${ }^{4}$ The restaurants in the Spanish pavilion, featuring tapas and Spanish wines alongside exhibitions of works by Pablo Picasso, Salvador Dalí and Juan Miró, were an often-remarked culinary highlight of Expo '88, not least for their novel tastes and the then innovatory manner of composing a meal from a series of small tasting-plates of food. Signage and marketing material were in both English and Spanish, with a brochure explaining that: 'No por casualidad la gastronomía juega un papel esencial en el ocio de España' — 'Gastronomy has always had an important part in the lives of the Spanish' (Spanish Pavilion 1988). Two decades on, foods from all of these once largely unfamiliar cuisines are widely available in Brisbane restaurants, takeaway venues and supermarkets.

The display of the Saitama (Japanese) Prefecture, a sister-state to Queensland, although it did not have a restaurant, café or other food outlet, similarly featured then exotic food products that have now become commonplace fare in Australia, such as green tea, rice crackers and smoked trout. Largely, however, pavilions without nationally themed restaurants paid scant attention to culinary matters in their displays. The Australian pavilion, for instance, profiled Australia's 'lively arts' - characterised as theatre, film, dance, music and other entertainment — but did not include any significant display of the restaurant industry that had been booming since the late 1970s in the capital cities at least. California, today one of the world's 'foodie' capitals and already known in 1988 for its wine regions and central valley produce-growing area, focused instead on sport. Even the French pavilion, which featured a recreation of an open-air French street café, utilised this space for hosting artistic workshops rather than profiling the distinguished reputation of French chefs and cuisine. Just as surprisingly, given the enduring popularity of Italian food, the Italian pavilion concentrated on design and there was no Italian-themed eatery at Expo '88. 


\section{Food as Entertainment}

When focus group research in 1986 identified that the principal potential market for Brisbane's expo wanted the event to be 'a celebratory party', the entertainment budget was quadrupled (Carroll 1988: 3). In direct contravention of the Paris-based Bureau International des Expositions (BIE), which endorses expositions on the condition that their principal purpose is 'the education of the public' (BIE 1928), the Commissioner-General of Expo '88 confirmed that visitors should expect 'entertainment, enjoyment and relaxation', and that education, 'though important, has necessarily taken a lesser role' (Williams 1988: 2). Food, and especially the acts of eating and drinking, formed an integral part of this entertainment program. The expansive Munich Festhaus tavern, the largest Expo '88 restaurant with seating for more than 1,200 patrons, served beer, sauerkraut, sausages and bread to the accompaniment of a Bavarian brass band. A repeat visitor remembers:

We'd all get together on Friday nights at a friend's house and get on the train to go to Expo; there might be a big group of us. It was something to look forward to and something to do. We'd get there and all start off at the German Beer Hall and order the big Steins of beer. (quoted in Anderson 2003: 408)

The Queensland seafood buffets offered aboard the Kookaburra Queen paddlewheeler restaurant provided another popular entertainment. Moored alongside the restaurants and cafés sited on the riverside boardwalk, and one of a pair launched in 1986 and 1988, this 30 metre-long vessel was modelled on a traditional American steam paddlewheeler, but powered by a 350 horsepower engine and built mainly from Queensland timbers.

Other well-patronised hospitality venues at Expo had a long history of repurposing. The Ship Inn, for instance, has had a presence on the site since it was built in 1865 as a private residence and was licensed as a hotel in 1879 under that name. Situated near a railway, dry dock and wharves, the hotel changed hands and lessees regularly and was repeatedly altered, renovated and built on to. In 1979 , filthy and derelict, the hotel was closed, although its licence remained in place, and in 1984 the property was resumed by the Expo Authority and extended to three times its size. During Expo, its licence was extended to 24 hours a day (Metcalf 2007). ${ }^{5}$

Other food-related entertainment included a daily picnic-themed lunchtime parade. Led by a marching band, floats featured a salad roll carried by ants, a typical barbecue scene, a Giuseppe Arcimboldo-type figure composed entirely of foodstuffs, and a wedding party. Norm, the portly 'couch potato' from the 'Life. Be in it.' advertisements, reclined on his sofa, drinking beer and watching an oversized television set. The parade was completed by an echidna, in pursuit of the ants that were played by performers on high stilts. The parade's producer, Mike Mullins, said its aim was to celebrate 'Australian ingenuity and creativity' (quoted in Cowell 1988: 39). In what was claimed to be a world's first, the floats were fully automated - but they served a more immediate need in providing 
diversion for the crowds queuing to enter pavilions. A series of food-related events held outside Expo was also advertised as part of its entertainment program. These events included regional food promotions such as 'A Taste of Tasmania', which featured television chef Bernard King, and a number of Australian Bicentennial Authority-funded food-related festivals held in and around Brisbane.

\section{Food as Pedagogical, Marketing and Symbolic Tool}

Food was also utilised for educational, as well as promotional and marketing, purposes, and these functions often overlapped. To these ends, recipe books, pamphlets and other practical information about foods and food preparation were distributed in a number of pavilions. A regular column under the title of 'Cooks Tour of Britain' in The British Times Expo, a free fortnightly newspaper guide to the British Pavilion, featured what it called 'typical' British foods. These included a ham and chicken pie with aspic and hot water pastry, and a chilled summer soup of lettuce, spinach and cucumber garnished with cream and fresh herbs, the recipe for which, the column claimed, came from 'a great house in Shropshire' (15-28 August 1988: 8). The South Pacific Trade Commission distributed a free booklet of coconut recipes. Despite being written by an Australian - Gloria Oxford, author of the 'Take-a-Hint' column in the popular weekly women's magazine, New Idea - the recipes include a series of authentic (and then unusual) dishes including fresh coconut sambal salad, coconut fish curry and a sago pudding utilising both canned coconut milk and fresh coconut. ${ }^{6}$

Food also played a ceremonial role at Expo '88. On 30 April 1988, Queen Elizabeth II opened the event in the presence of the prime minister, Queensland's new Premier Mike Ahern, Brisbane's Lord Mayor Sallyanne Atkinson, 7,000 invited VIP guests, a proportion of that day's 77,260 paying visitors and whoever tuned in to the live television telecast. Afterwards, a much-publicised luncheon was hosted by the prime minister and his wife on behalf of the government for the Queen and invited guests, with all three courses featuring local produce. The well-conceived, surprisingly light menu was entirely suitable for the warm sub-tropical spring day, and reveals the pervasive influence of nouvelle cuisine and its focus on fresh seafood, vegetables and fruit - especially notable as Queensland was (and is) a major beef and pork producer. The meal opened with a selection of what were termed 'Queensland delicacies': king prawns, Moreton Bay bugs and Queensland scallops served, presumably chilled, with avocado and a lime mayonnaise. This was followed by a second seafood dish, a pearl perch poached in fish fumet, offset with beurre blanc sauce and seasonal vegetables. A 'feast of Queensland fruits with sorbets' formed the dessert course, with macadamia nuts, crystallised ginger petits fours and coffee to finish. Although Queensland had an emerging wine industry, the wines served were from renowned Australian vineyards outside the state. ${ }^{7}$ This meal was significantly different to those usually served to visiting Royal family members and other dignitaries, which commonly comprised a preponderance of red meat, and were described almost entirely in French. This emphasis on fresh, 
light, local and seasonal produce was much more aligned with the modern ways of cooking and eating that were then being championed by leading chefs such as Melbourne's Stephanie Alexander and California's Alice Waters.

The Australian Pavilion, with an operating budget of somewhere between $\mathrm{A} \$ 18$ million and $\mathrm{A} \$ 22$ million, was visited by over 2.5 million people, and some 16,000 of these attended 310 official functions consisting of formal luncheons and dinners, receptions, buffets, suppers and breakfasts (Veivers 1988: 4; O'Brien 1991: 307). In addition, the official luncheons on the 'national days' - on which each exhibiting country profiled itself - were held in the Australian pavilion. Alongside these official functions, the pavilion also provided an almost unremitting stream of casual hospitality. Although these functions were recognised by organisers as assisting 'in promoting Australia and our profile to the World', there were times when the level of hospitality was perceived as being detrimental to the image Australia was trying to project: 'It was felt that the Pavilion's identity was compared to a restaurant to be hired rather than being the host Pavilion for the Nation.' (Veivers 1988: 5)

\section{Celebration of a Nation?}

Although the Bicentenary was marketed with the slogan 'Celebration of a Nation' and (in common with most international expositions) Expo '88 was, at least in part, conceived by its organisers as an extravagant advertisement for its host city, ${ }^{8}$ the expo was also expected to service the Australian Bicentennial Authority's objective of 'achieving international participation in the Bicentenary' (quoted in Spillman 1997: 97) and a recognition of Australia's place in the world. This was clearly articulated by Prime Minister Hawke, who stated that although 1988 would be a 'year of national celebration', it would also be 'a year in which we will demonstrate to the world that we are a nation moving ahead with confidence' (Hawke 1986: 771). The Expo Authority had simultaneously ascertained that, although multiple visits by domestic, and particularly local, residents would ensure the event's success, the potential to attract these visitors was understood to relate directly to the amount of cultural diversity it could market as an attraction (Carroll 1988: 2; Birch 2005: 81). In this, the Expo Authority recognised how international expositions, in Anderson's reckoning, 'present opportunities for people to explore the world outside their everyday experience and to encounter different cultures' (2003: 401). This was, however, at odds with a widely held — although rarely officially articulated - fear that raising any of a range of potentially problematic issues (including those of ethnic and racial difference) could lead to the disruption of Bicentennial events.

Although there was some reticence to sign up, 39 countries were duly represented as individual international exhibitors at Expo '88, as were the European Community (with each of its multitude of publications in all of the EU's official languages) and the United Nations. Although the Middle East, Latin and South America, Scandinavia, Eastern Europe and, apart from Kenya, most of Africa 
were not represented, the pre-event marketing underscored the number, diversity and all-inclusiveness of the countries involved: 'From the world super powers to the tiny island nations, they'll all be there.' (Earnshaw 1987: 14) Visitors were, indeed, promised that they could 'travel the globe without leaving the comfort of Queensland's sub-tropical climate' (WE88 1988 'Together'). A popular Expo souvenir was the replica passport, which could be stamped at each pavilion as a record of a 'visit to nations from throughout the world' (WE88 1988 'Passport'). This 'tour' ranged from the familiar to the exotic, from 'the United Kingdom and historic Europe to the intrigue of Russia, China and Asia, from the sophistication of North America to the rugged untouched wilderness of Africa and the beauty of the Pacific' (WE88 1988 'Passport'). At a time when Brisbane was the most ethnically homogeneous capital city in Australia, the paying public embraced this concept, with one couple of season passholders expressing gratitude that Expo ' 88 had 'given us one last chance to see the world' (Catchpole 1988, quoted in McGregor 1998-2007).

As discussed above, food played a major part in this creating this sense of an international experience. However, despite this, the catering available at Expo '88 was not a feature of the substantial pre-event advertising and marketing campaign, the main goal of which was to sell discounted season tickets, with the percentage of discount sliding as the opening approached. A survey of the substantial collection of pamphlets and other promotional material for Expo '88 held by the National Library of Australia reveals only a single brochure that gave any consideration to the food available. In promising 'a gourmet tour of the world ... a gourmet's delight ... a taste sensation', this brochure described how the exposition would offer 'everything from Japanese sushi to New Zealand trout, and the delicacies of the South Pacific'. However, this description pulled back from the exotic to focus on the familiar, continuing to explain:

You can visit the 112-year-old 'Ship Inn' for some traditional Aussie 'tucker', or sample venison in the New Zealand Hunting Lodge, or you may just like to relax on the floating paddlewheeler restaurant, sampling the best seafood the local waters have to offer. (WE88 'Announcing World Expo')

Additional information about less well-known cuisines was decidedly muted: 'As well as the many on-site restaurants, some international pavilions serve their own traditional mouthwatering fare.' (WE88 'Announcing World Expo')

By the time of the event's closure, Expo '88 organisers were proudly proclaiming high visitor numbers, large profits and huge amounts of foods and drinks sold as evidence of success. ${ }^{9}$ Ticket sales had passed nine million before the opening (Carroll 1988: 4), and by the closure a total of 18,574,476 visits had been made (including VIPs and staff, and 16,465,000 non-staff). This was 70 per cent more than the most optimistic projections, and a total that exceeded (as was repeatedly pointed out) Australia's total population (NCSTT 1988). ${ }^{10}$ The A $\$ 140$ million spent on food and beverages comprised almost two-thirds of the on-site expenditure of 
A\$230 million, excluding entry fees (NCSTT 1989). However, despite the range of (authentic or otherwise) international comestibles available, these visitors consumed a vast amount of highly familiar food and drinks. Their purchases included some sixteen million scoops of ice cream, seventeen million hamburgers, 1.4 million hot dogs, 5 million chicken nuggets, 8 million buckets of hot potato chips, 700,000 meat pies, 340 trawler-loads of seafood and enough of the 76 brands of beer available to fill 650 family swimming pools. Although 1.3 million cups of fruit juice were sold, it was the $\mathrm{A} \$ 40$ million worth of alcoholic beverages sold on site that made the headlines (Aubin 1988b; McGregor 1998-2007). ${ }^{11}$

\section{After World Expo '88}

Some found Expo '88 an accomplishment of national and international proportions. The Commissioner-General's report to the BIE stated that the 'tyranny of distance that we in this country have heard so much about ... has hopefully either been laid to rest or put into proper perspective by the multitude and type of international visitors' (Williams 1988: 1). Others disagreed, with a report funded by the Commonwealth Minister for Local Government finding the expo had 'widespread, well documented, if not readily quantifiable, negative personal and social impacts on the people of South Brisbane and West End' (Day 1988: iv). Studies ascertained that inflated rental costs, the reduced availability of rental housing and forced evictions negatively affected the composition of the community, which was also impinged upon by the increased noise levels and the economic losses suffered by many small local businesses, which included food-related venues (Day 1988: 42-43). Despite this, Brisbane's image as sleepy and old-fashioned was, without doubt, ousted by what Wanna and Caulfield have described as 'the party atmosphere surrounding Expo' when large numbers of Brisbane residents felt the city 'came alive' (1995: 44). At the formal opening, Brisbane's mayor announced: 'Today we formally and officially become an international city.' (Atkinson, quoted in Felton 2007: 144) Many have reiterated this view that Expo '88 made a major contribution to Brisbane's 'coming of age'.

This modification was purposeful, with the head of the Expo Authority confirming that: 'Our basic aim has been to make World Expo '88 the catalyst for a significant change in our lifestyle.' (Edwards, quoted in Sanderson 2003: 66) It largely revolved around dining habits, with Expo '88 ushering in not only extended opening hours for restaurants and hotels, and the introduction of sidewalk cafes with outdoor eating facilities, but the extension of all retail trading hours for inner Brisbane until 4.00 p.m. on Saturdays (from midday) and introducing Sunday trading (which had previously been limited to an extremely restricted list of business types). ${ }^{12}$ The Industrial Commission later approved continuing these trading hours after the event. Others have noted that, as a direct result of Expo '88, Brisbane residents, visitors and those in the hospitality and retail industries had heightened expectations of both the range of foods and cuisines that should be available, and the quality of service personnel. Before the event, exposition 
staff had delivered what were known in the Brisbane service industry as 'Be Nice' hospitality standard improvement sessions to some twenty thousand hotel and restaurant staff and shopkeepers, as well as to bus and taxi drivers and customs officials (Robson 1988: 54).

After the pavilions and their food service areas were dismantled and removed, together with the freestanding Lockwood Lodge, Pacific Village Lagoon and Japanese Tsuruya restaurants, it was feared that depression would become a significant problem in Brisbane, since research showed that other world exposition host city inhabitants had experienced widespread 'Post-Expo blues' (Aubin 1988a). 'Expo Anonymous', a telephone hotline referring callers to counselling services, was well patronised in the months after closure (Roberts 1988: 3). However, unlike many other exposition sites that have fallen into disuse or been totally demolished, the Brisbane site has been in a state of progressive redevelopment since Expo '88 closed, with a competition for the future redevelopment of the site promptly held and obtaining considerable community input. Despite concerns that the redevelopment would exclude Brisbane's public as a combination of 'tourist, commercial and genteel residential living for those who can afford it' (Craik 1989: 109), the winning scheme — for public parklands — was announced in August 1989. The resulting Southbank Parklands development has indeed been characterised as 'Brisbane's backyard': an idealised resort, with open-air eateries in a tropical landscaped setting 'for a population who could only dream of such luxury at home' (Bull, quoted in Noble 2001).

Today, twenty years after World Expo '88, the Southbank Parklands precinct hosts a number of popular restaurants, cafés, hotels and takeaway outlets (including self-described Australian, Chinese, Greek, Indian, Italian, Japanese, Malaysian, Mediterranean, Thai, Turkish, Vietnamese and fusion cuisines), of which a number are a direct legacy of Expo '88 and the lifestyle innovations it introduced to Brisbane. It appears, moreover, that the event and its food have lived on in individual memory. Anderson's study of visitors' long-term memories of such expositions (including Expo '88) found that the most dominant and vivid recollections centred on shared social interactions. Such recollections were significantly more pronounced than those concerned with the information presented in the pavilions or other displays. This study listed 'having dinner at a restaurant or café on the Expo site' as a recurrent memory among visitors (2004: 407, 408) and such research adds weight to the assertion that visitors, as well as the host city, were irrevocably affected by World Expo '88.

\section{Acknowledgement}

Research for this article was completed while I was a Residential Fellow at Manning Clark House, Canberra in 2007.

\section{Works Cited}

Anderson, D. 2003, 'Visitors' Long-term memories of world expositions', Curator, 46.4, 400-20. Aubin, Tracey 1988a, 'Expo city facing post-party blues', Sydney Morning Herald, 17 October, 3. 
Aubin, Tracey 1988b, 'Why Sir Llew can now say: I told you so', Sydney Morning Herald, 31 October, 4.

Bennett, Tony 1992, 'The shaping of things to come: Expo '88' in Celebrating the Nation: A Critical Study of Australia's Bicentenary, eds Tony Bennett, Pat Buckridge, David Carter and Colin Mercer, Allen \& Unwin, Sydney, 123-41.

Birch, Ric 2005, Master of the Ceremonies: An Eventful Life, Allen \& Unwin, Sydney.

British Pavilion 1988, 'Britain in Brisbane' [brochure], NLA, General Ephemera: World Expo '88.

Bureau International des Expositions (BIE) 1928, Bureau International des Expositions Convention, Part 1, 22 November, Paris.

Carroll, Peter 1988, 'A complicated web: The management of World Expo '88', Australian Administration Magazine, 3.3, $2-4$.

Carroll, Peter and Donohue, Kerry 1989, 'Accounting for Expo '88', Directions in Government, 3.1, 61-62, 64.

Cotterell, John J. 1990, 'Youth leisure patterns and World Expo', Youth Studies: Bulletin of the National Clearinghouse for Youth Studies, 9.1, 10-16.

Cowell, Andrew, ed., 1988, World Expo '88. The Official Souvenir Program, Australian Consolidated Press, Sydney.

Craik, Jennifer 1989, 'The Expo experience: The politics of expositions', Australian-Canadian Studies, 7.1-2, 95-111.

Day, Phil 1988, The Big Party Syndrome: A Study of the Impact of Special Events and Inner Urban Change in Brisbane, Department of Social Work, University of Queensland, St Lucia.

Earnshaw, A., ed., 1987, Your Personal Invitation to World Expo '88 [booklet inserted in The Weekend Australian, the Sunday Telegraph (Sydney), The Sun-News pictorial (Melbourne), The Advertiser (Adelaide), the Sunday Times (Perth), 24-25 October], NLA, General Ephemera: World Expo '88.

Felton, Emma 2007, Becoming Urban: A Social and Cultural Study of Urban Change in Brisbane, $\mathrm{PhD}$ thesis, Griffith University, Brisbane.

Fry, Tony and Willis, Anne-Marie 1988, 'Expo '88: Backwoods into the future', Cultural Studies, 2.1, 127-38.

Gregory, Michael L. 1990, 'Brisbane 1988: World Expo '88', in Historical Dictionary of World's Fairs and Expositions, 1851-1988, eds John E. Findling and Kimberly D. Pelle, Greenwood Press, New York, 366-68.

Hawke, Bob 1986, 'Expo '88. Speech at the International Planning Meeting of World Expo '88, in Brisbane on 9 September', Australian Foreign Affairs Record, 57.9, 771-73.

Jones, Scott, Bray, David and Phillips, Juanita 1988, Expo! An Independent Review, Boolarong Publications, Brisbane.

Marketing World 1987/1988, 'Bicentennial licensing reaches a high', Marketing World, 7.10, 62.

Matheson, P. \& Randle, L. (c1988) 'Nelson: The Sunshine State of New Zealand. Marlborough: A Gourmet's Paradise' [information sheet] (NLA, General Ephemera: World Expo '88).

McGregor, John 1998-2007, Foundation Expo '88, www.foundationexpo88.org/indexfoundation. html.

McKay, Judith 2004, Showing Off: Queensland at World Exhibitions, 1862-1988, Central Queensland University Press and Queensland Museum, Rockhampton.

McHoul, Alec 1989, 'Not going to Expo: A theory of impositions', Meanjin, 48.2, 213-22.

Metcalf, Bill 2007, 'The Ship Inn hotel: A story of South Brisbane and Southbank', Journal of the Royal Historical Society of Queensland, 20.2, 31-49.

Morgan, Murray Cromwell and Wilson, Steven C. 1963, Century 21: The Story of the Seattle World's Fair, 1962, Acme Press, Seattle.

National Capital Development Commission (NCDA) 1988, Visit Canberra at World Expo '88 Brisbane [pamphlet], NLA, General Ephemera: World Expo '88. 
National Centre for Studies in Travel and Tourism (NCSTT) 1989, Expo '88 Impact: The Impact of World Expo '88 on Queensland's Tourism Industry [report], Queensland Tourist and Travel Corporation, Brisbane.

National Museum of Australia (NatMus) 2007, Australia at Expo 67 Montreal [exhibition], www. nma.gov.au/exhibitions/australia_at_expo_67.

Noble, Louise 2001, 'South Bank Dreaming', Architecture Australia, September/October, www. archmedia.com.au/aa/aaissue.php?issueid=200109\&article=15\&typeon=2.

O'Brien, Denis 1991, The Bicentennial Affair: The Inside Story of Australia's 'Birthday Bash', Australian Broadcasting Commission, Sydney.

Oxford, Gloria 1988, Coconut Recipes [brochure], NLA, General Ephemera: World Expo '88.

Philippine Pavilion 1988, 'Fiesta at the Philippine Pavilion' [brochure], NLA, General Ephemera: World Expo '88.

Roberts, Greg 1988, 'Expo blues: The show is gone, but the malady lingers on', Sydney Morning Herald, 12 December, 3.

Robinson, Richard N.S. 2007, 'Plain fare to fusion: Ethnic impacts on the process of maturity in Brisbane's restaurant sector', Journal of Hospitality and Tourism Management, 14.1, 70-84.

Robson, Frank 1988, 'Great Expo-tations', Australian Women's Weekly, May, 53-55.

Sanderson, Rachel 2003, 'Queensland shows the world: Regionalism and modernity at Brisbane's World Expo '88', Journal of Australian Studies, 79, 65-76.

Spanish Pavilion 1988, Pavilion of Spain: World Expo '88 [brochure], Forma TG, Madrid, NLA, General Ephemera: World Expo '88.

Spillman, Lyn 1997, Nation and Commemoration: Creating National Identities in the United States and Australia, Cambridge University Press, Cambridge.

Sri Lankan Pavilion 1998, 'Sri Lanka Pavilion Restaurant Menu' [pamphlet], NLA, General Ephemera: World Expo '88.

Swiss Pavilion 1988, 'The Terrace' [folding business card], NLA, General Ephemera: World Expo '88.

Syvret, Paul 1988, 'The Business Side of Expo', Australian Business, 8.25, 4 May, 52-53, 56-57.

USSR Pavilion 1988, 'USSR Expo '88' [pamphlet], NLA, General Ephemera: World Expo '88.

Vaccaro, Pamela J. 2004, Beyond the Ice Cream Cone: The Whole Scoop on Food at the 1904 World's Fair, Enid Press, St Louis, MO.

Van Oudtshoorn, Nic 1988, 'Accounting for World Expo '88', Australian Accountant, 58.7, August, $12-15$.

Veivers, T. 1988, 'Executive Report: Australian Pavilion. World Expo '88', 30 October.

Walsh, Anthony and Hall, James 1988, World Expo '88, Robert Brown \& Associates, Bathurst.

Wanna, John and Caulfield, Janice, eds, 1995, 'Brisbane: A City in Transition', in Power and Politics in the City: Brisbane in Transition, Macmillan Education, Melbourne, 34-46.

Williams, Edward 1988, Report of the Hon. Sir Edward Williams, KCMG, KBE, CommissionerGeneral of Expo '88, to be presented to the Ambassador for Australia His Excellency Mr E.R. Pocock, to the General Assembly of the Bureau of International Expositions in Paris on 14 December 1988.

World Expo '88 (WE88) 1988, Announcing World Expo '88 [brochure], SouthBank, Brisbane, NLA, General Ephemera: World Expo '88.

World Expo '88 (WE88) 1988, Passport [booklet], NLA, General Ephemera: World Expo '88.

World Expo '88 (WE88) 1988, Together We'll Show You the World [brochure], Southbank, Brisbane, NLA, General Ephemera: World Expo '88.

Wurts, Richard and Appelbaum, Stanley 1977, The New York World's Fair, 1939/1940 in 155 Photographs, Dover, New York. 


\section{Notes}

1 In April 1989, a week-long festival was held to celebrate the first anniversary of Expo's opening. A modest photographic exhibition at the State Library of Queensland marked the ten-year anniversary, while a series of twentieth anniversary events (including those organised by anti-Expo protesters) were scheduled to be held in 2008. Important studies include Fry and Willis (1988); Jones, Bray and Phillips (1988); McHoul (1989); and Cotterell (1990).

2 It was later calculated that Expo '88 created the equivalent of some 58,929 full-time (one year long) jobs (NCSTT 1989).

3 Event planning was led by the Queensland state government's Brisbane Exposition and South Bank Redevelopment Authority (widely known as 'the Expo Authority'), established in 1984, with Brisbane City Council co-coordinating the necessary town, transport and other city services planning. Both reported to the event's ostensible host, the Australian government, through the Australian Bicentennial Authority.

4 Soups: juhe paradajz chorbr (tomato and noodle) and pasulj corba (lima bean and ham); entrees: sunka sa jajima (double-smoked ham), lignje na zaru (fried squid), domaca kobasica (sausage) and goulash, followed by, for main course: cevapcici (ground meat rolls), raznijici (pork brochettes), Balkan (pepper and garlic) steak and orada (grilled bream). Desserts included a dabosa tortei (gateau) and European-style strudel.

5 Trading poorly post-Expo, in 1997 the premises became a catering school. In 2000, Griffith University purchased and refurbished the building, removing many of the Expo additions and including seminar and lecture rooms alongside a café and bar.

6 'Sago Pudding: 6 cups coconut milk, 1/2 cup sago, 1 cup freshly grated (or shredded) coconut, $1 / 4$ cup sugar. Bring to the boil in a saucepan and simmer until sago grains are plump and clear. Beat a little of the sago together with 2 eggs. Stir into the sago mixture, simmer for a few minutes. Serve with coconut cream. Serves 6-8.' (Oxford 1988)

$7 \quad$ Served were Lindemans' Hunter River Riesling (Semillon) Bin 3855 1970, Tyrrell's Chardonnay Vat 471984 and Hardy's Reserve Beerenauslese 1984, with a Seppelts' Brut 1985 for the Loyal Toast.

8 The Australian Pavilion's Commissioner-General noted that the 'Commonwealth's general attitude and lack of commitment to the project [particularly in the planning stages] allowed the Expo Authority to promote the Expo as a "Queensland affair"" (Veivers 1988: 16).

9 Accounting has subsequently revealed that, despite substantial indirect government subsidies, Expo '88 incurred deficits of between A $\$ 22.6, \$ 130$ and $\$ 420$ million (Carroll 1988: 4; Carroll and Donohue 1989: 62; Van Oudtshoorn 1988; Gregory 1990: 368).

10 Some 65.4 per cent of visitors were South-East Queenslanders on day trips, 6.1 per cent Queenslanders on overnight trips, 23.2 per cent interstate visitors on overnight trips and 5.3 per cent $(870,000)$ from overseas (NCSTT 1988; O’Brien 1991: 237).

11 Some 94 per cent of this alcohol consumption was beer, 5.1 per cent was wine and less than 1 per cent was spirits.

12 At this time, the 'normal hours of work' were redefined as those between 7.00 a.m. and midnight, seven days a week, with an extra loading for work between midnight and 7.00 a.m. (Carroll 1988: 4). 